\title{
Coral reproduction on the world's southernmost reef at Lord Howe Island, Australia
}

\author{
Andrew H. Baird ${ }^{1, *}$, Vivian R. Cumbo ${ }^{1}$, Sallyann Gudge ${ }^{2}$, Sally A. Keith ${ }^{1,3}$, \\ Jeffrey A. Maynard ${ }^{4,5}$, Chun-Hong Tan ${ }^{1,6}$, Erika S. Woolsey ${ }^{1}$
}

${ }^{1}$ ARC Centre of Excellence for Coral Reef Studies, James Cook University, Townsville, QLD 4811, Australia ${ }^{2}$ NSW Department of Primary Industries, Lord Howe Island Marine Park, PO Box 161, Lord Howe Island, NSW 2898, Australia

${ }^{3}$ Center for Macroecology and Evolution, University of Copenhagen, Universitetsparken 15, 2100 Copenhagen, Denmark ${ }^{4}$ Department of Ecology and Evolutionary Biology, Cornell University, Ithaca, NY 14853, USA

${ }^{5}$ Laboratoire d'Excellence «CORAIL» USR 3278 CNRS-EPHE, CRIOBE, Papetoai, Moorea, French Polynesia ${ }^{6}$ School of Marine Science and Environment, Universiti Malaysia Terengganu, 21030 Kuala Terengganu, Terengganu, Malaysia

\begin{abstract}
Despite a recent expansion in the geographic extent of coral reproductive research, there remain many regions in the Indo-Pacific where knowledge is limited. For example, Lord Howe Island is the southernmost reef system in the world $\left(31^{\circ} \mathrm{S}\right)$; however, very little is known of the reproductive biology of the coral fauna. Here, aspects of the reproductive biology and the timing of reproduction for 40 of the approximately 65 species that occur on Lord Howe Island are documented. In December 2010, field assessments of the stage of gamete maturity in Acropora spp. colonies suggested that 5 species spawned in December 2010 and 11 in January 2011. In January 2012, similar sampling suggested that 12 Acropora species spawned in January and 1 in February. In addition, 11 species from 10 genera broadcast spawned gametes from 17:30 to 24:00 h in January 2012, 10 to $12 \mathrm{~d}$ after full moon. Goniastrea favulus was inferred to spawn prior to 17:00 h, 6 to $12 \mathrm{~d}$ after full moon and Porites heronensis released brooded larvae. The reproductive biology of 3 other brooding species was examined using dissections and histology monthly for $1 \mathrm{yr}$ from April 2011. Of these, Seriatopora hystrix contained planulae between November 2011 and March 2012, Stylophora pistillata contained planulae between November 2011 and February 2012. No eggs or planulae were observed in Pocillopora damicornis. In conclusion, the spawning patterns on Lord Howe Island are consistent with other locations in the Indo-Pacific: multi-species synchronous spawning episodes occur after full moons, when water temperatures are relatively high.
\end{abstract}

KEY WORDS: Coral reefs $\cdot$ Larval ecology $\cdot$ Spawning timing $\cdot$ Egg size

\section{INTRODUCTION}

Coral reproductive research in the Indo-Pacific has been concentrated historically in regions close to marine research stations in developed countries (see review by Baird et al. 2009b). However, coral reproduction is increasingly recognised as a fundamental process to maintain ecosystem function within coral reefs and, as such, interest in improving our understanding of this process has grown rapidly. In addition, recognition that ecological processes are

\footnotetext{
*Corresponding author: andrew.baird@jcu.edu.au
}

often context-dependent suggests we should seek to quantify reproductive phenology across a wide geographic extent. Whilst the geographic focus of coral reproductive research has recently expanded to include more remote regions such as India (Raj \& Edward 2010), New Caledonia (Baird et al. 2010), the Persian Gulf (Bauman et al. 2011) and Yemen (Baird et al. 2014), reproductive phenology on marginal reefs at the extreme geographical limits of coral distributions has yet to be quantified. Corals on marginal reefs would be expected to be the least con-

(C) The authors 2015. Open Access under Creative Commons by Attribution Licence. Use, distribution and reproduction are unrestricted. Authors and original publication must be credited. 
sistent with a broader pattern and, therefore, offer potential to determine the limits of reproductive phenology.

The increased geographical extent across which reproductive phenology has been quantified has altered our understanding of coral reproductive synchrony and the processes that regulate the timing of coral reproduction (Baird et al. 2009b, van Woesik 2010). For example, highly synchronous spawning, both within and among species, is not restricted to higher latitude reefs as earlier hypothesized (Oliver et al. 1988). In particular, multi-species synchronous spawning events (sensu Willis et al. 1985) are now described for $>25$ locations globally (Baird et al. 2009b, Kongjandtre et al. 2010, Bouwmeester et al. 2011, Permata et al. 2012). In addition, coral reproduction in most regions is highly seasonal, with the vast majority of reproductive activity concentrated in 2 to 3 months each year (Baird et al. 2009a). This trend holds in equatorial locations (e.g. Singapore: Guest et al. 2005; e.g. Kenya: Mangubhai \& Harrison 2008) and in regions where breeding patterns had previously been described as aseasonal (e.g. the Red Sea: Shlesinger \& Loya 1985) due to incomplete sampling (Hanafy et al. 2010, Bouwmeester et al. 2015).

Despite this recent expansion in the geographic extent of studies on coral reproduction, there remain many regions in the Indo-Pacific where research is limited. For example, Lord Howe Island contains the southernmost reef system in the world $\left(31.53^{\circ} \mathrm{S}\right.$, $\left.159.08^{\circ} \mathrm{E}\right)$; and is a World Heritage-listed marine protected area in the Tasman Sea, with highly distinctive marine fauna including 9 endemic fish species (Francis 1993) and 47 endemic species of algae (MPA 2010). Lord Howe Island supports a scleractinian fauna of approximately 65 species (Veron 1993); however, almost nothing is known of the reproductive biology of these corals, in particular the timing of spawning and the length of the reproductive season. Goniastrea favulus was observed broadcast spawning at approximately 16:30 h 'during mid-January, 1977' (Kojis \& Quinn 1981), 6 Acropora spp. and Cyphastrea microphthalma were observed setting (immediately prior to spawning) or spawning 8 to 9 nights after the full moon, and Isopora cuneata planulated 9 nights after the full moon in January 2007 (Harrison 2008). In addition, local tourist operators often run nighttime snorkelling trips to observe corals spawning following the full moon in February (P. Busteed pers. comm.). The reproductive biology of high-latitude corals, such as those on Lord Howe Island, is of particular interest, because these populations are often geographically isolated (Noreen et al.
2009) and therefore replenishment is likely to be highly dependent on local reproductive output or irregular input of propagules from distant upstream reefs (Fellegara et al. 2013, Madsen et al. 2014).

Most broadcast-spawning colonies spawn only once per year (Harrison \& Wallace 1990, Baird et al. 2009b). In contrast, oogenic cycles are much shorter in corals that brood larvae (e.g. Stoddart \& Black 1985, Permata et al. 2000), and consequently individual colonies can release larvae multiple times per year. For example, individual colonies of Pocillopora damicornis, Seriatopora hystrix and Stylophora pistillata release larvae throughout the year at Palau, whereas at Heron Island, on the southern Great Barrier Reef, breeding is seasonal (see review in Tanner 1996). Similarly, Isopora palifera releases planulae throughout the year in Papua New Guinea, but only in the summer months on Heron Island (Kojis 1986).

The highly seasonal nature of coral reproduction has important implications for reef ecology and conservation (Guest 2008). Numerous reef organisms, including many fishes, time their reproductive cycles to benefit from this seasonal abundance of nutrients (Pratchett et al. 2001, McCormick 2003). In addition, knowledge of coral reef phenology allows the use of temporal management strategies that can mitigate the effects of coastal development on coral reefs (Richmond 1997). For example, dredging or discharge of liquid waste from heavy industry can be prohibited during coral spawning, ensuring that the seasonal production of propagules for reef replenishment is not jeopardized (Baird et al. 2011).

In this study, we document the day or month of propagule release for 34 of the approximately 65 coral species on Lord Howe Island. We also document aspects of the reproductive biology of many of these species, including the sexual system, mode of larval development, transmission of Symbiodinium spp. and egg size on release.

\section{MATERIALS AND METHODS}

\section{Reproductive condition of Acropora species}

Acropora were sampled 8 to $10 \mathrm{~d}$ before full moon on 21 December 2010, and 3 to $5 \mathrm{~d}$ after full moon on 9 January 2012. These sampling times were chosen because previous work on Lord Howe Island indicated that Acropora spp. spawn 8 to $10 \mathrm{~d}$ after full moon (Harrison 2008). Twenty-three Acropora spp. were sampled to determine their reproductive condition (for full list of species see Table 1). Three repro- 


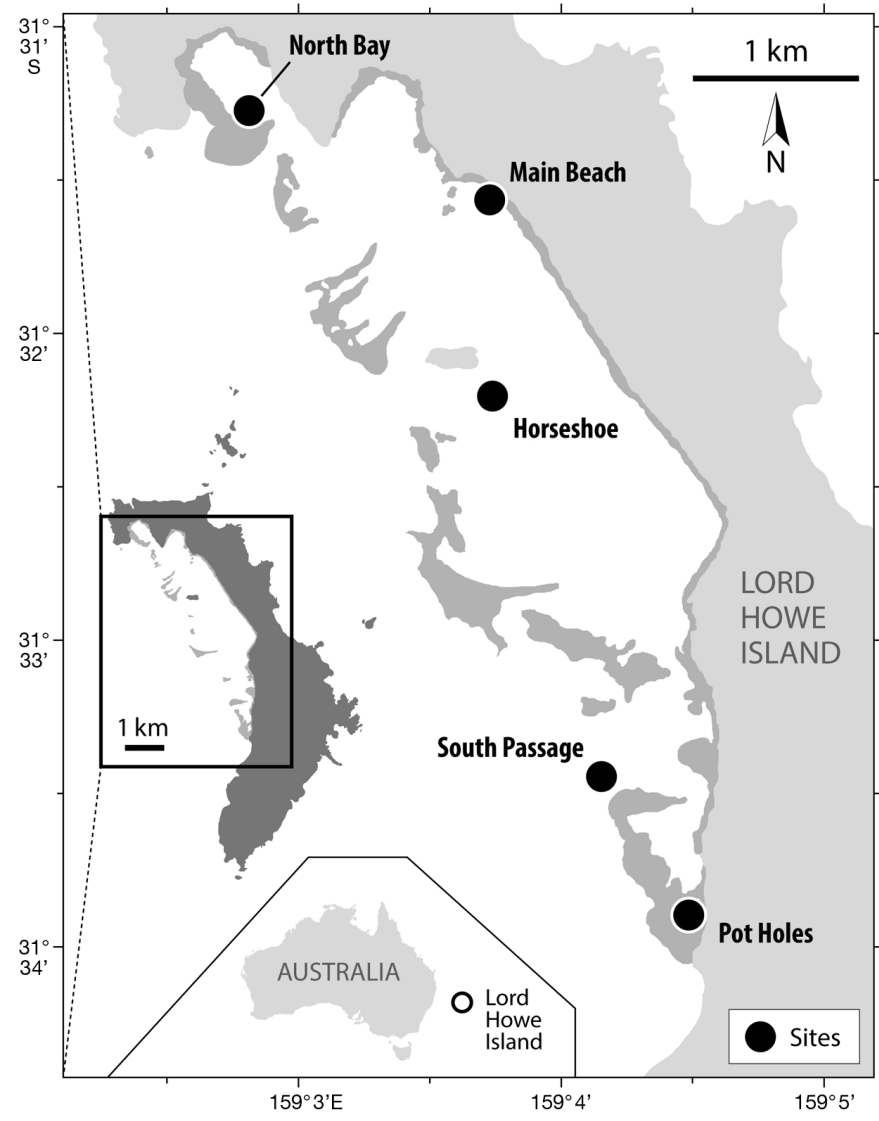

Fig. 1. Map showing the 4 collection sites at Lord Howe Island: North Bay, Horseshoe, South Passage and Pot Holes. All sites were within the lagoon, and the corals were collected 1 to $2 \mathrm{~m}$ below tidal datum. Mid-grey shadings are areas of coral reef

ductive conditions were defined (sensu Baird et al. 2002) based on the appearance of the oocytes as observed with the naked eye in the field: (1) mature-oocytes pigmented and assumed to be released within a month; (2) immature-oocytes pale but visible, indicating that they are close to maturity and assumed to be released within $2 \mathrm{mo}$; and (3) empty - oocytes too small to see or absent, indicating either that the colony has recently released its gametes, or is unlikely to do so for at least 3 mo.

\section{Observations of coral reproductive behaviour in aquaria}

Mature coral colonies for spawning observations were collected from 1 to $2 \mathrm{~m}$ below tidal datum at 4 sites (North Bay, Pot Holes, Comet's Hole, South Passage) in the lagoon on Lord Howe Island (Fig. 1) between 16 and 20 January 2011 and were stored under the jetty during daylight hours (for species list see Table 2). Colonies were submerged in buckets and transported to the research station each day at 17:30 $\mathrm{h}$, where they were maintained until 08:00 $\mathrm{h}$ the following morning, with 1 complete seawater change at 24:00 h. Colonies were inspected approximately every $30 \mathrm{~min}$ while at the research station to capture the onset of spawning. Egg colour, whether or not eggs were released in bundles, whether or not eggs contained Symbiodinium spp., and the maximum diameter of the spherical eggs were recorded. Egg size was measured to the nearest unit under a dissecting microscope with a stage micrometer and graticule eyepiece at a magnification of $\times 40$ from 2 to $6 \mathrm{~h}$ after egg release.

\section{Reproductive biology of species in the family Pocilloporidae}

To determine the reproductive condition of 3 species of pocilloporid corals (Pocillopora damicornis, Seriatopora hystrix, Stylophora pistillata), 1 branch, approximately $5 \mathrm{~cm}$ long, was collected from each of 5 colonies of each species monthly from April 2011 until March 2012 inclusive in the week before the full moon of each month. The fragments were preserved in $10 \%$ seawater formaldehyde and then decalcified in a mixture of $90 \%$ water and $10 \%$ formic acid and preserved in $70 \%$ ethanol. Five polyps were dissected from each branch under a stereo-microscope and the numbers of oocytes and planulae in each polyp were counted. Oocytes and planulae of the Pocilloporidae are readily distinguished under a stereo-microscope on the basis of size: oocytes rarely have a diameter $>100 \mu \mathrm{m}$ (Permata et al. 2000). The type of reproductive tissue was confirmed through histology. Sections of the decalcified branches containing reproductive tissues were embedded in wax following dissections, sectioned at $7 \mu \mathrm{m}$ thickness, and 3 to 4 sections approximately $50 \mu \mathrm{m}$ apart were mounted on slides. Slides were stained using Mayer's haematoxylin and Young's eosin-erythrosine (Baird et al. 2011).

\section{Environmental variables associated with coral spawning}

Environmental variables hypothesized to serve as proximate cues by which coral synchronise spawning (see review in Baird et al. 2009b) were collated and their association with the timing of spawning on Lord 
Howe Island illustrated graphically. This included monthly mean seasurface temperatures (SST), photosynthetically available radiation (PAR), rainfall and wind speeds. Mean SSTs were calculated for the period 19822010 using the NOAA Pathfinder dataset v5.2. SSTs for 2010 and 2012 SSTs were calculated from the on-reef sensor network of the Great Barrier Reef Ocean Observing System and the Australian Institute of Marine Science (http://data.aims.gov.au/gbroos/). Mean monthly PAR was calculated for the period 1999-2010 using data from NASA (MODIS; http://oceancolor. gsfc.nasa.gov/). Mean monthly rainfall and wind speed data were obtained for the period 1999-2010 using data from NASA/NOAA (TMI, wWw.remss.com/missions/tmi).

\section{Species identifications}

Acropora spp. were identified in situ or from photographs or microscopic examination of the skeleton following Wallace (1999). Species from other families were similarly identified following Veron (2000). The most recently accepted names for these species were then determined by a search at the World Register of Marine Species (www.marinespecies.org/index.php). Many of the corals on Lord Howe Island are highly distinctive and difficult to place within current morphological species boundaries. Indeed, there are likely to be a number of undescribed species, including at least 4 we examine here that will be described elsewhere.

\section{RESULTS}

\section{Stage of oocytes maturity of Acropora species}

Between 12 and 14 December 2010, 83 colonies were sampled from 13 species (Table 1). Eighteen percent of colonies were mature, $58 \%$ were immature and $24 \%$ were empty. Four species had at least 1 mature colony and 11 species had colonies that were immature (Table 1). Only 1 species was not gravid (i.e. neither mature nor immature oocytes were detected) at the time of sampling (Table 1).
Coral spawning slicks were observed on 29 December 2010 (Fig. 2a), 8 d after full moon.

Between 12 and 14 January 2012, a total of 158 colonies were sampled from 18 species. Fifty-four percent of colonies were mature, $45 \%$ were empty and 1 colony was immature (Table 1). Twelve species had at least 1 mature colony and 6 species were not gravid (Table 1). Coral spawning slicks were observed on 19 January 2012 (Fig. 2b), $10 \mathrm{~d}$ after the full moon. Extensive field samples on 20 and 21 January 2012 found no Acropora colonies with mature oocytes.

\section{Reproductive biology and spawning times of corals maintained in aquaria}

Of the 15 species collected for observation in the laboratory, broadcast spawning was observed in 11 species and 1 species, Porites heronensis, released planulae that were swimming when first observed at 09:00 $\mathrm{h}$ in the morning (Table 2). Broadcast spawning was inferred to occur in Goniastrea favulus on the basis of disappearance of mature oocytes from all 5 


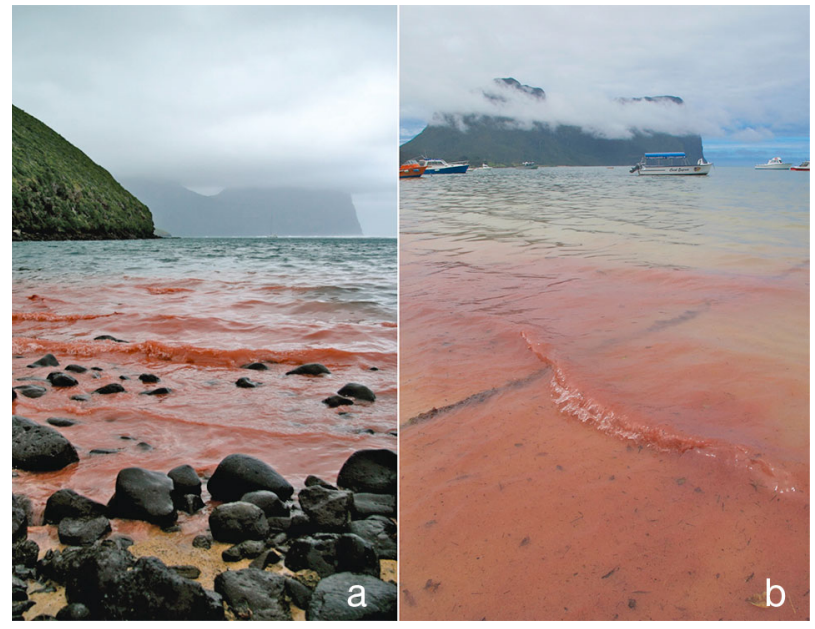

Fig. 2. Coral spawn slicks at Lord Howe Island: (a) North Bay, 29 December 2010, and (b) Main Beach, 19 December 2012

colonies at some point between initial collection of colonies on 13 January and a subsequent check of reproductive condition on 20 January 2012. We assumed these colonies spawned before 17:00 $\mathrm{h}$ when colonies were brought to the laboratory from storage under the jetty for observation. None of the 10 Acropora colonies spawned in the laboratory (Table 2); however, neither species had any oocytes in extensive sampling in the field on 20 January 2011. Of the species observed in the aquaria, 5 spawned on 19 January 2012, $10 \mathrm{~d}$ after the full moon, 6 on 20 January, and 3 on 21 January (Table 2). Acanthastrea hillae spawned 30 min before sunset, Favites halicora and 1 colony of Platygyra daedalea spawned sometime between 00:00 and 06:00 $\mathrm{h}$ the next morning, and the remainder of species spawned between 20:30 and 00:00 h (Table 2). Species observed to broadcast-spawn gametes were hermaphrodites (i.e. both eggs and sperm were apparent in gamete bundles), with the exception of Goniopora norfolkensis, in which bundles contained only eggs. Egg diameters on release ranged from a minimum of $284 \mu \mathrm{m}$ in the 2 Cyphastrea species to $484 \mu \mathrm{m}$ in A. hillae (Table 2). Only $P$. heronensis had Symbiodinium spp. in its propagules (Table 2).

\section{Reproductive biology of species in the family Pocilloporidae}

Oocytes were first observed in 3 out of 5 colonies of Seriatpora hystrix in October 2011. Two colonies had oocytes in November, 5 in December and January, and 2 in February. Typically, there were only 1 or 2 oocytes per polyp. Planulae were first observed in

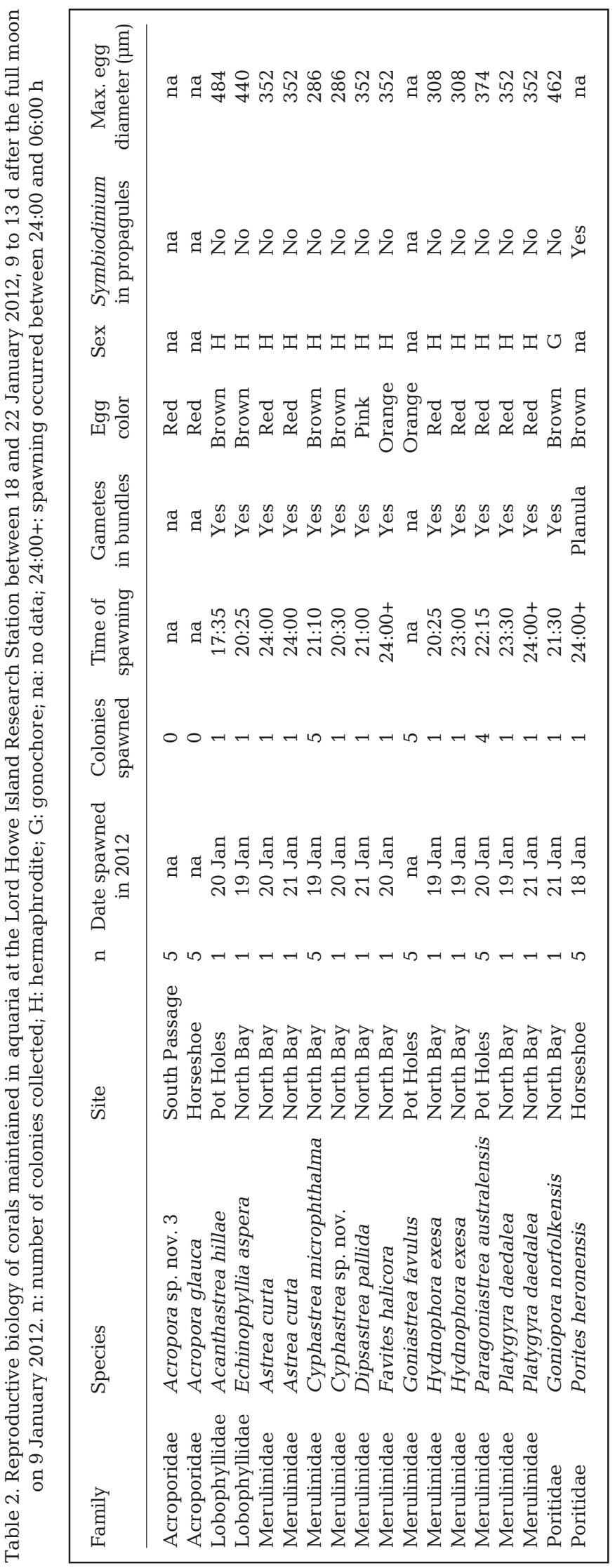


2 colonies of S. hystrix in November 2011. Five colonies had planulae in December; 3, in January; none, in February; and 2, in March. Typically, 1 planula was found in each polyp and very occasionally 2 . Oocytes were first observed in all 5 colonies of Stylophora pistillata in October 2011. All 5 colonies had oocytes in November; 3 in December; 2 in January and none in February or March. Up to 9 oocytes were observed in a polyp. Planulae were first observed in 3 out of 5 colonies of S. pistillata in November 2011. Four colonies had planulae in December and 2 had them in January. Typically 1 or 2 planulae were found in each polyp, although up to 4 planulae were observed in a single polyp. No oocytes or planulae were observed in Pocillopora damicornis.

\section{Gametogenic cycles and development of planulae in pocilloporids}

Samples for histology were first processed from colonies collected in October 2011 at which time, for S. hystrix, both oocytes and spermaries were evident in cross-section (Fig. 3a). Developing larvae were first observed in November 2011, at which point spermaries, oocytes and the developing larvae all cooccur in the same branch (Fig. 3b). The largest oocytes observed were approximately $140 \mu \mathrm{m}$ (Fig. 3b). Larvae were distinguished by their size (200 to $450 \mu \mathrm{m}$ in diameter in cross-section; Fig. 3b,c), deep redstaining yolk cells and an epidermis (Fig. 3c,d). Planulae were first observed in November and were distinguished by a well-differentiated gastrodermis and an epidermis with nematocysts and gland cells (Fig. 3e,f). Planulae were approximately 450 to $550 \mu \mathrm{m}$ in cross-section (Fig. 3e,f).

\section{Environmental conditions during spawning}

Spawning at Lord Howe Island coincided with rising SST and occurred prior to the historical peak in SST of $24^{\circ} \mathrm{C}$ in March and April (Fig. 4a). Coral spawning occurred when PAR was at a maximum (Fig. 4b), monthly rainfall was relatively high (Fig. 4c), and wind speeds were relatively low when compared to other months (Fig. 4d).

\section{DISCUSSION}

Here, we documented the month or time of spawning of more than half of the approximately 65 species on Lord Howe Island. Multi-specific synchronous spawning episodes occurred between dusk and midnight, 8 to $12 \mathrm{~d}$ after full moons in December and January. Peak reproductive activity most probably occurs in January, because 24 species were either observed or inferred to spawn over a 3 to 4 night period, 8 to $11 \mathrm{~d}$ after the full moon in January 2012 and 3 species also released planulae in January 2012. Spawning in December and January coincides with high and rising SST, high PAR, high rainfall and low wind speeds for the location. These spawning patterns are similar to most other locations in the IndoPacific (Baird et al. 2009b).

The proportion of Acropora spp. colonies and the number of species inferred to spawn in January were similar in both years - $58 \%$ of the colonies from 11 species in 2010 versus $54 \%$ of the colonies from 12 species in 2012 (Table 1) - suggesting that this is the typical pattern. The high proportion of colonies gravid (76\%) in December 2010 suggests that reproductive activity is unlikely to be strong in months other than December and January. Nonetheless, 5 of the 23 Acropora spp. sampled were not gravid. These 5 species either breed at other times of the year, not at all, or, alternatively, not enough colonies were sampled to detect gravid individuals. High reproductive output in December and January coincides with peaks in coral recruitment to settlement tiles placed between December and March (Harriott 1992).

The sexuality and mode of reproduction of each species are similar to previous records in the IndoPacific (Baird et al. 2009b). Novel observations include the first record of the mode of reproduction in Acanthastrea hillae and Cyphastrea sp. nov., which are both broadcast spawners, and Porites heronensis, which is a brooder. $P$. heronensis is highly abundant in the lagoon at Lord Howe Island, and, together with other species known to brood on Lord Howe Island or elsewhere (Seriatopora hystrix, Stylophora pistillata, Isopora cuneata, P. damicornis), makes up >60\% of the coral cover in the lagoon (Keith et al. 2015). The dominance of brooding species in coral assemblages at Lord Howe Island was first noted by Harriott (1992) who hypothesised that rapid settlement of brooded larvae allows these species to establish populations in isolated locations such as Lord Howe Island. An alternative hypothesis is that internal fertilization (i.e. brooding) is a more successful reproductive strategy than external fertilization (i.e. broadcast spawning) in the sub-tropical waters of Lord Howe Island. In 2 species of broadcast spawners, median larval lifespan was very low: $<24 \mathrm{~h}$ for both Paragoniastrea australensis and Cyphastrea 

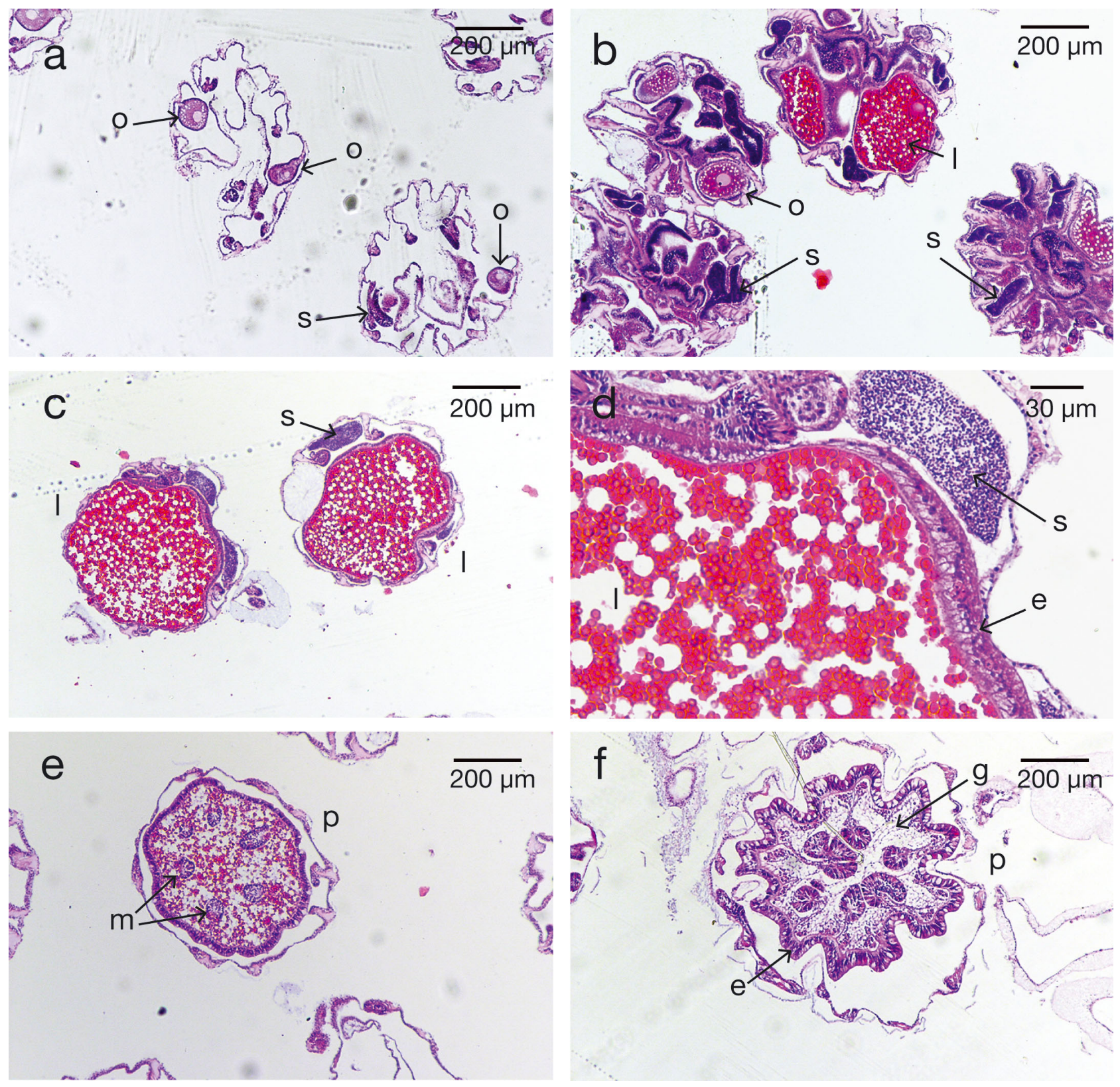

Fig. 3. Gametogenic cycles and development of brooded planulae in Seriatopora hystrix at Lord Howe Island: (a) oocytes in polyps in October 2011; (b) oocytes, spermaries and developing larvae in polyps in November 2011; (c) developing larvae, distinguished by their size ( $300 \mu \mathrm{m}$ diameter), deep red-staining yolk cells, and epidermis, and spermaries in adjacent polyps in November 2011; (d) close-up of developing larvae showing epidermis; (e) larvae in polyps with developing mesenteries and epidermis in November 2011; and (f) fully developed planula larvae in a polyp in December 2011. o: oocytes; s: spermaries; l: developing larvae; p: planulae; m: mesenteries; e: epidermis; g: gastrodermis

microphthalma (Woolsey et al. 2014) compared to typical values of $>30 \mathrm{~d}$ among the larvae of broadcast-spawning species at tropical locations (Graham et al. 2008, Connolly \& Baird 2010). This suggests that gametes of these sub-tropical broadcast-spawning corals were either of poor quality or highly sensitive to handling. Poor-quality larvae could be attributed to the marginal environmental conditions experienced in Lord Howe Island waters, such as winter temperatures of $14.4^{\circ} \mathrm{C}$ (Woolsey et al. 2014). This might have a detrimental effect on the development of gametes in broadcast-spawning species that have an oogenic cycle of between 6 and 14 months (Harrison \& Wallace 1990). In contrast, brooding species 

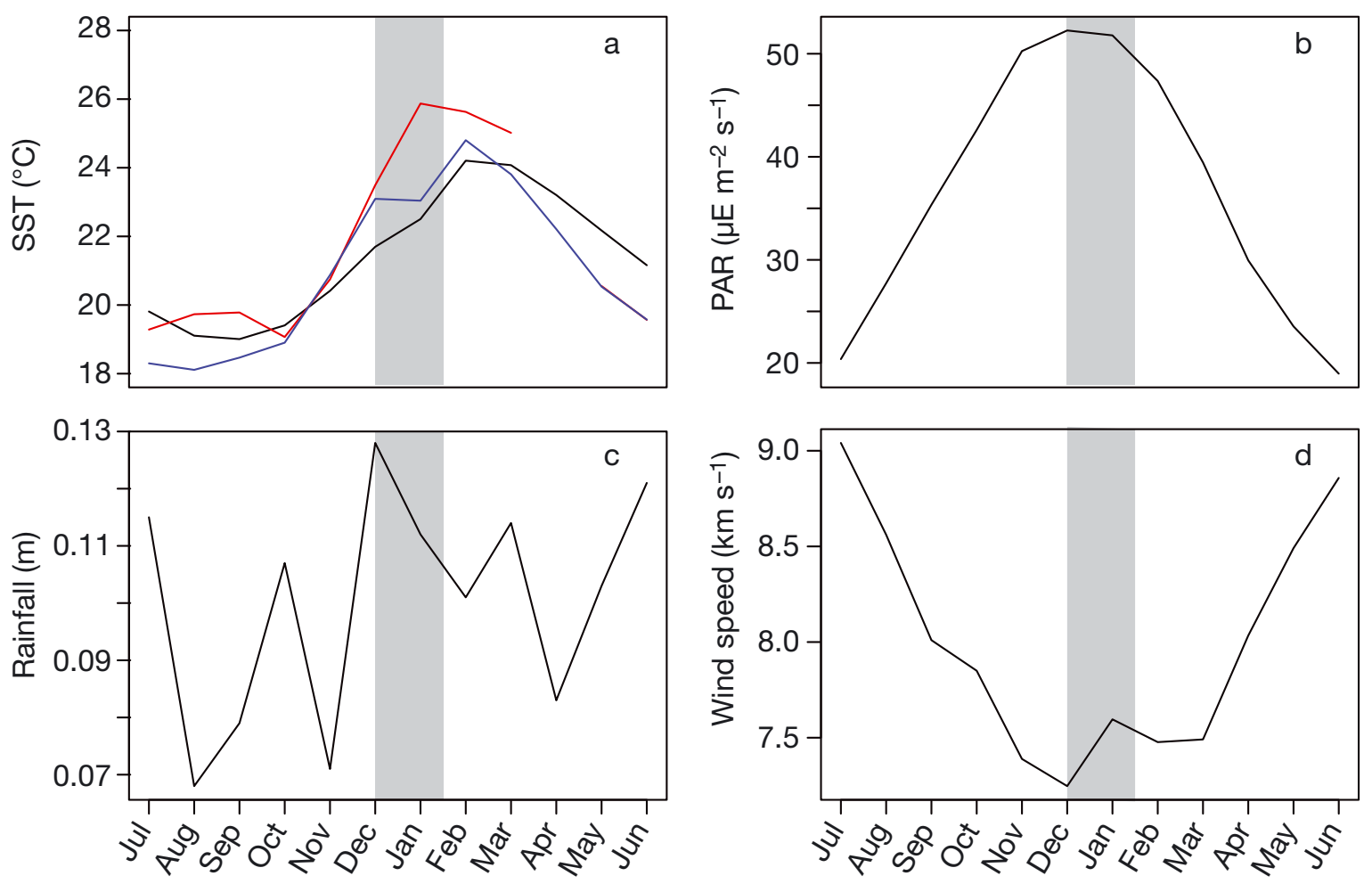

Fig. 4. Environmental variables hypothesised to be involved in synchronising coral spawning: (a) mean monthly sea-surface temperature (SST) for the period 1982-2010 (black line), 2010 (red line) and 2012 (blue line); (b) mean monthly photosynthetically active radiation (PAR); (c) mean monthly rainfall; and (d) mean monthly wind speeds for the period 1999-2010 (data sources are listed in the 'Materials and methods' section). Spawning times are indicated by the grey shading in each panel

have an oogenic cycle of approximately $1 \mathrm{mo}$, and only breed in the warmer months of the year on Lord Howe Island. Low survivorship of broadcast-spawned propagules is consistent with the low densities of recruits to settlement tiles on the substratum at Lord Howe Island when compared with settlement in tropical locations (Harriott 1992).

Oocytes and larvae were first observed in Seriatopora hystrix and Stylophora pistillata in October and November, respectively, suggesting an oogenic cycle of approximately 1 mo in these 2 species. Dissections suggested that oocytes were produced monthly and co-occur in the same polyps with developing larvae (Fig. 1b). Planulae are likely to be released shortly after maturity, indicating most colonies will planulate every month over a period of 3 to $4 \mathrm{mo}$. The length of the reproductive season in these brooders at Lord Howe Island is similar to that at Heron Island but contrasts with the period at more tropical locations where planulation occurs throughout the year (Fan \& Dai 1996, Tanner 1996). In contrast, no reproductive activity was observed in Pocillopora damicornis: neither oocytes nor planulae were recorded in 300 polyps from a possible 60 colonies over a complete year of sampling. Despite previous conjecture (see citations in van Woesik 1995), this is the first time no reproductive activity has been detected in a scleractinian coral species in the absence of obvious stress. This result is possibly a sampling artefact. If the time to develop from oocyte to planulae is $<1$ mo then the monthly sampling could have missed the cycle. Indeed, previous estimates of a $2 \mathrm{wk}$ oogenic cycle in $P$. damicornis in Okinawa indicate this is a possibility (Permata et al. 2000). Further work is required to establish whether or not $P$. damicornis is reproductively active at Lord Howe Island.

The patterns of spawning within the coral assemblage at Lord Howe Island indicate that patterns in marginal reef locations are similar to those in locations elsewhere in the Indo-Pacific. This suggests that the selective processes that drive spawning synchrony are the same as those found in other regions of the Indo-Pacific. The highly seasonal nature of coral reproduction at Lord Howe Island and elsewhere means that managing human activities to reduce the threat from processes that affect reproductive success, such as dredging, appears quite feasible once the timing of these events is established. 
Acknowledgements. We thank Brian Busteed and the staff at Howea Divers, Ian Kerr and the staff at the NSW Department of Primary Industries on Lord Howe Island and the Lord Howe Island Board. We also thank R. van Hooidonk for assisting with compiling environmental data. This project was funded by Australian Research Council grants to A.H.B.

\section{LITERATURE CITED}

Baird AH, Marshall PA, Wolstenholme J (2002) Latitudinal variation in the reproduction of Acropora in the Coral Sea. In: Proc 9th Int Coral Reef Symp, Vol 1. International Coral Reef Society, Bali, p 385-389

Baird AH, Birrell CL, Hughes TP, McDonald A and others (2009a) Latitudinal variation in reproductive synchrony in Acropora assemblages: Japan vs. Australia. Galaxea 11:101-108

Baird AH, Guest JR, Willis BL (2009b) Systematic and biogeographical patterns in the reproductive biology of scleractinian corals. Annu Rev Ecol Evol Syst 40:551-571

Baird AH, Kospartov MC, Purcell S (2010) Reproductive synchrony in Acropora assemblages on reefs of New Caledonia. Pac Sci 64:405-412

Baird AH, Blakeway DR, Hurley TJ, Stoddart JA (2011) Seasonality of coral reproduction in the Dampier Archipelago, northern Western Australia. Mar Biol 158:275-285

$>$ Baird AH, Abrego D, Howells EJ, Cumbo VR (2014) The reproductive season of Acropora in Socotra, Yemen [v2; ref status: indexed, http://f1000r.es/392]. F1000Res 3:78, doi:10.12688/f1000research.3846.2

Bauman AG, Baird AH, Cavalcante GH (2011) Coral reproduction in the world's warmest reefs: southern Persian Gulf (Dubai, United Arab Emirates). Coral Reefs 30: 405-413

- Bouwmeester J, Khalil MT, De La Torre P, Berumen ML (2011) Synchronous spawning of Acropora in the Red Sea. Coral Reefs 30:1011

Bouwmeester J, Baird AH, Chen CJ, Guest JR, Vicentuan KC, Berumen ML (2015) Multi-species spawning synchrony within scleractinian coral assemblages in the Red Sea. Coral Reefs 34:1-13

> Connolly SR, Baird AH (2010) Estimating dispersal potential for marine larvae: dynamic models applied to scleractinian corals. Ecology 91:3572-3583

Fan TY, Dai CF (1996) Reproductive ecology of the pocilloporid corals in Taiwan. I. Seriatopora hystrix. ACTA Oceanogr Taiwan 35:311-321

Fellegara I, Baird AH, Ward S (2013) Coral reproduction in a high-latitude, marginal reef environment (Moreton Bay, south-east Queensland, Australia). Invertebr Reprod Dev 57:219-223

Francis MP (1993) Checklist of the coastal fishes of Lord Howe, Norfolk, and Kermadec Islands, Southwest Pacific Ocean. Pac Sci 47:136-170

> Graham ER, Baird AH, Connolly SR (2008) Survival dynamics of scleractinian coral larvae and implications for dispersal. Coral Reefs 27:529-539

Guest J (2008) How reefs respond to mass coral spawning. Science 320:621-623

> Guest JR, Baird AH, Goh BPL, Chou LM (2005) Reproductive seasonality in an equatorial assemblage of scleractinian corals. Coral Reefs 24:112-116

> Hanafy M, Aamer M, Habib M, Rouphael AB, Baird AH (2010) Synchronous reproduction of corals in the Red
Sea. Coral Reefs 29:119-124

Harriott VJ (1992) Recruitment patterns of scleractinian corals in an isolated subtropical reef system. Coral Reefs 11:215-219

> Harrison PL (2008) Coral spawn slicks at Lord Howe Island, Tasman Sea, Australia; the world's most southerly coral reef. Coral Reefs 27:35

Harrison PL, Wallace CC (1990) Reproduction, dispersal and recruitment of scleractinian corals. In: Dubinsky Z (ed) Coral reefs. Elsevier, Amsterdam, p 133-207

Keith SA, Woolsey E, Byrne M, Madin JS, Baird AH (2015) Differential establishment potential of species drives a shift in coral assemblage structure across a biogeographic barrier. Ecography, doi:10.1111/ecog.01437

Kojis BL (1986) Sexual reproduction in Acropora (Isopora) (Coelenterata: Scleractinia). 2. Latitudinal variation in A. palifera from the Great Barrier Reef and Papua New Guinea. Mar Biol 91:311-318

Kojis BL, Quinn NJ (1981) Aspects of sexual reproduction and larval development in the shallow water hermatypic coral, Goniastrea australensis (Edwards and Haime, 1857). Bull Mar Sci 31:558-573

> Kongjandtre N, Ridgway T, Ward S, Hoegh-Guldberg O (2010) Broadcast spawning patterns of Favia species on the inshore reefs of Thailand. Coral Reefs 29:227-234

Madsen A, Madin JS, Tan CH, Baird AH (2014) The reproductive biology of the scleractinian coral Plesiastrea versipora in Sydney Harbour, Australia. Sex Early Dev Aquat Org 1:25-33

> Mangubhai S, Harrison PL (2008) Asynchronous coral spawning patterns on equatorial reefs in Kenya. Mar Ecol Prog Ser 360:85-96

McCormick MI (2003) Consumption of coral propagules after mass spawning enhances larval quality of damselfish through maternal effects. Oecologia 136:37-45

MPA (Marine Parks Authority) (2010) Lord Howe Island Marine Park: zoning plan review report. NSW MPA, Sydney, p 132. www.mpa.nsw.gov.au/pdf/lhimp-zp-reviewreport.pdf

Noreen AME, Harrison PL, Van Oppen MJH (2009) Genetic diversity and connectivity in a brooding reef coral at the limit of its distribution. Proc R Soc Lond B 276:3927-3935

Oliver JK, Babcock RC, Harrison PL, Willis BL 1988. Geographic extent of mass coral spawning: clues to ultimate causal factors. In: Proceedings of the 6th International Coral Reef Symposium, Vol 2. Symposium Executive Committee, Townsville, p 803-810

Permata WD, Kinzie RA III, Hidaka M (2000) Histological studies on the origin of planulae of the coral Pocillopora damicornis. Mar Ecol Prog Ser 200:191-200

> Permata D, Indrayanti E, Haryanti D, Fika L, Arfiyan H, Achmad A (2012) Biannual multispecific spawning in Karimunjawa Archipelago, Indonesia. Coral Reefs 31:907

> Pratchett MS, Gust N, Goby G, Klanten SO (2001) Consumption of coral propagules represents a significant trophic link between corals and reef fish. Coral Reefs 20:13-17

Raj KD, Edward JKP (2010) Observations on the reproduction of Acropora corals along the Tuticorin coast of the Gulf of Mannar, southeastern India. Indian J Mar Sci 39:219-226

Richmond RH 1997, Reproduction and recruitment in corals: critical links in the persistence of reefs. In: Birkeland $\mathrm{C}$ (ed) Life and death of coral reefs. Chapman \& Hall, New York, NY, p 175-197 
Shlesinger Y, Loya Y (1985) Coral community reproductive patterns: Red Sea versus the Great Barrier Reef. Science 228:1333-1335

Stoddart JA, Black R (1985) Cycles of gametogenesis and planulation in the coral Pocillopora damicornis. Mar Ecol Prog Ser 23:153-164

Tanner JE (1996) Seasonality and lunar periodicity in the reproduction of pocilloporid corals. Coral Reefs 15:59-66

van Woesik R (1995) Coral communities at high latitude are not pseudopopulations: evidence of spawning at $32^{\circ} \mathrm{N}$, Japan. Coral Reefs 14:119-120

van Woesik R (2010) Calm before the spawn: global coral spawning patterns are explained by regional wind fields. Proc R Soc Lond B 277:715-722

Editorial responsibility: Judith Grassle, New Brunswick, New Jersey, USA
Veron JEN (1993) A biogeographic database of hermatypic corals. Australian Institute of Marine Science, Townsville Veron JEN (2000) Corals of the world. AIMS, Townsville

Wallace CC (1999) Staghorn corals of the world. CSIRO, Collingwood

Willis BL, Babcock RC, Harrison PL, Oliver JK (1985) Patterns in the mass spawning of corals on the Great Barrier Reef from 1981 to 1984. In: Gabrié C et al. (eds) Proceedings of the 5th Int Coral Reef Congress, Vol 4. Antenne Museum-EPHE, Moorea, p 343-348

Woolsey ES, Keith SA, Byrne M, Schmidt-Roach S, Baird $\mathrm{AH}$ (2014) Latitudinal variation in thermal tolerance thresholds of early life stages of corals. Coral Reefs, doi:10.1007/s00338-014-1253-z

Submitted: November 26, 2014; Accepted: February 14, 2015 Proofs received from author(s): April 2, 2015 